\title{
Alga as an Indicator of Water Quality in Fresh Water Bodies of Mysore, Karnataka, India
}

\author{
J. Mahadev ${ }^{1}$, G. Sugeetha ${ }^{2}$, N.S. Pankaja ${ }^{3}$ and K.V. Shivakumar ${ }^{4}$ \\ ${ }^{1}$ Environmental Sciences, ${ }^{2}$ Entomology, ${ }^{3}$ Plant Pathology, ${ }^{4}$ Crop Physiology, College of \\ Agriculture, V. C. Farm, Mandya, India \\ *Corresponding author:
}

Keywords

Algae, Palmer, Garrett, Louies-

Laclereq, Organic pollution

Article Info

Accepted: 20 February 2019 Available Online: 10 March 2019

\section{A B S T R A C T}

The paper attempts to give an account of fresh water algae as an indicator of water quality. Eight lakes of Mysore have been studied. The Palmers Index IDSELS Diatom index and OMNIDA software, were used for calculated and analysed. The order of tolerance to organic pollution was calculated using the Garrett ranking techniques. According to Palmer index all the eight lakes were organically polluted. Bogadi Lake was least polluted and Karanji Lakes and Mandakahalli Lake were polluted. The present investigation compares the use of old and new techniques of detecting the water quality. It also enables us to understand whether the algae are imparting organic pollution of lake water. The species index indicated that Bogadi Lake, Hadinarru Lake, Karanji Lake and Bilikere Lake had low organic pollution. The diatom index showed that all lakes ranged between moderate and high organic pollution but the degradation levels in the water was also high. Dalvoi Lake and Mandakahalli Lake had the highest organic pollution. Species of Euglena and Scenedesmus were the most tolerant species found in organic polluted lakes. Algae were found to be highly resistant in Karanji Lake, Dalvoi Lake, Kukkarahalli Lake and Bilekere Lake. These sites were found to be conducible for the growth of algae, while most of the other lakes had idiosynthcratic species. This study uses the advanced modern tools in determining levels of organic pollution in Lake Ecosystem.

\section{Introduction}

All major Lakes are facing acute pollution problem resulting in emission of foul odour, silt deposits and chocking due to excessive algal growth. The use of algae as a biological indicator, their diversity and distribution can be exploited for fish monitoring and surveillance for assessing the contaminants. Some notable work was done by Hosmani and Bharathi (1980), Hosmani and Naganandi
(1998), Mahadev and Hosmani (2005) Mahadev et al., (2008) and Mahadev et al., (2009) on "Algae as indicators of organic pollution", This study was done based on the classic work of Palmer (1969). Hosmani (2013) developed "Algal index of pollution based on the observation of 269 reports by 165 authors who reported that the algae were tolerant to organic pollution. The pollution index was scored based on the relative number of algae. The index has been used by several 
research palmer (1969), Nygoard (1976) Kelly (2006) Hosmani (2013) and Hosmani and mruthunjays (2013), more developed by Louies-Laclereq (IDSELS) 2008 and Lecointe (2003) which is based on the occurrence of only donation species in any water body.

Killy (2006) used diatoms and algae as indicator of ecological status and explained the precise method of sampling and calculating the water quality. This index not only estimates the organic pollution but also determines the percentage of anthropogenic pollution in the range between low and high. It also determines the degradation level of pollutants in the water. The present study investigates algae collected from eight Lakes of Mysore district and its surrounding. The sample collections were made seasonally for a period of two years from 2015 to 2017.

\section{Materials and Methods}

Mysore district lies between $11^{\prime} 39^{\circ}$ and $12^{\prime}$ $50^{\circ}$ north latitude and $75^{\prime} 45^{\circ}$ east longitude. It is situated in the southern part of Deccan peninsula and it is a southern district of Karnataka state. The district is distinctly featured by many numbers of water channels and Lakes fed by the river Cauvery and its tributaries. These are responsible for the development of major wetlands of the district. Additionally, rain fed fresh waters is also abundant.

\section{Sampling sites}

Sampling for algae was done from 8 Lakes which are situated at a distance of $15-22 \mathrm{kms}$ in and around Mysuru. These Lakes were contaminated due to various anthropogenic activities. Some of the Lakes become occasionally dry but again gets inundated through channels. The water of all Lakes was light green, green in colour and also aquatic plants like Ipomea, Typha, Pistia, Lemna,
Eichhornia, Numphea, Azolla and Potamogeton were commonly found.

\section{Collection of water sample and analysis}

Water samples and sediments were collected from 8 Lakes for 2years 2015-2017. The samples were collected in $30 \mathrm{ml}$ vials and few drops of Lugol's iodine and $4 \%$ formaldehyde were added, labelled and stored. Identification and enumeration of algae were done by Lackey's drop method (1938) slightly modified by Saxena (1987). Algae were identified using the monographs of Desikachary (1959), Prescott (1982) Seatt and Prescott (1961), Philipose (1960), Gandhi (1998) Taylor et al., (2007). The software Ominida GB 5.3 was used to calculate the Louis-Laclereq Index (Lecointe, 2003). The order of merit given by Palmer's algal index (1969) was converted into different ranks by using the formula Percentage position $=10(\mathrm{Rj}$ - 0.5)/ $\mathrm{Nj}$ where $\mathrm{Rj}$; Rank given for the ith item, jth individual and $\mathrm{N}=$ number of items ranked by the $\mathrm{j}$ th individual. The percentage position of each rank thus obtained was converted into scores by referring to the table given by Henry G. Arreett (1924). Each score of the index was added and divided by the total number of observations (number of Lakes). The mean score of all the factors was arranged in the order of their ranks and interpreted. Altemate to these indices Blanco and Blanco (2012) have used the Duro Batom index using weighted average method to derive autoecological profiles of water chemistry. Idiosyncratic species in polluted Lakes were determined according to the software developed by Atmar and pallerson, 1995.

\section{Results and Discussion}

The results of the indices for the eight Lakes are given in table 1-4. The highest organic pollution index was reported in Karanji Lake, 
Dalvoi Lake, Kukkrahalli Lake, and Bilikere Lake. The values ranged between a minimum of 20 to a maximum of 33 . The least index was observed in Bogadi Lake. Species like Euglena, Oscillatoria, Scenedesmus and Synedra appeared in all Lakes and are the most prominent indicators of organic pollution. The twenty algal species tolerant to organic pollution are shown in table 2. Among hese species, Euglena acus, Sceneslesmus quadricauda and Synedrauina were found to be the most tolerant species. The scores 14 to 22 were taken as probable evidence of high organic pollution. The lower values in Bogadi Lake and Hadhinaru Lake indicated that the organic pollution was low. In the present study, it was observed that all the 8 Lakes were organically polluted. The species index gave an indication that Bogadi and Hadhinaru Lakes categorised as low organic polluted (Total score of 14) was tending to be organically polluted.

The Louis-Laclereq (2008) index of pollution derived from the OMNIDA GB 5.3 is presented in table 2. The percentage indicator of organic pollution was very high in Dalvoi Lake, Kukkrahalli Lake and Bilikere Lake. The level of organic pollution was low in Bogadi Lake and Shetty Lake. The table also depicts the level of disturbance by human activity. Dalvoi Lake and Karanji Lake were heavily polluted due to human interference while the rest of the Lakes were highly disturbed. Only two Lakes Kukkrahalli and Bilikere Lakes were moderately disturbed. The two Lakes Bogadi and shetty Lakes were less disturbed. The index was derived mainly on the basis of the abundance and distribution of diatom species throughout the period of study. Diatom cells often remained for a long duration and hence can serve as an important indicator of organic pollution as well as anthropogenic activity (Hosmani, 2010). The Garrett ranking technique (1824) is an important tool in attributing the rank. According to this technique, the ranking of each Lake is presented in table 3. The highest pollution was observed in Dalvoi Lake (ranking 1) followed by Karanji Lake (ranking 2). The least polluted Lakes were mandakahalli and Hadhinaru Lake. The rankings of remaining Lakes lie between moderate values (Table 4). This ranking enables researchers to select Lakes for conservation strategies.

The presence of algae indicated whether they were indigenous to each of the Lakes or were accidentally introduced whenever there were rains or by human activity which survived only for few months (allocathonous). The autocathonous algae usually (origin within the Lake itself) completed their life cycles in the Lakes. Some algae resulted as blooms during certain seasons. In the present study, Dalvoi Lake, Karanji Lake and kukkrahalli Lake were judged to be the most hospitable sites. While the Lakes shetty, Hadhinaru and Bogadi did not support the growth and distribution of the algae. The genera Euglena and Synedra had similar niche requirements and were found to be more common and prevalent in these Lakes. These were most resistant to extinction and replaced the species of the genera Gomphonema and Oscillatoria. However species of the genera Ankistrodesmus, Cyclotella and chlorella were highly sensitive to environmental conditions and therefore appear occasionally.

The species of Euglena, Scenesdesmus lepoeinclis and Synedra were highly resistant and were autocathonous in origin and appear regularly in almost all Lakes. The Lakes can be reorganized in descending order (Atmar and Patterson, 1995). Many of the genera selected as indicator of organic pollution by palmer index (1969) are those which were idiosyncratic (or) those that appeared occasionally when the environmental conditions were favourable. Probably they were predominant during all seasons and each author has reported based on their presence. 
Table.1 Algal index of the genera

\begin{tabular}{|c|c|c|c|c|c|c|c|c|c|}
\hline Algal Genera & $\begin{array}{c}\text { Dalvoi } \\
\text { Lake }\end{array}$ & $\begin{array}{c}\text { Karanji } \\
\text { Lake }\end{array}$ & $\begin{array}{c}\text { Kukkrahalli } \\
\text { Lake }\end{array}$ & $\begin{array}{c}\text { Mandakahalli } \\
\text { Lake }\end{array}$ & $\begin{array}{c}\text { Shettykere } \\
\text { Lake }\end{array}$ & $\begin{array}{c}\text { Hadhinaru } \\
\text { Lake }\end{array}$ & $\begin{array}{c}\text { Bogadi } \\
\text { Lake }\end{array}$ & $\begin{array}{c}\text { Billikere } \\
\text { Lake }\end{array}$ & $\mathbf{P}$ \\
\hline Ankistrodesmus & 1 & 2 & - & 2 & - & - & - & - & 2 \\
\hline Chlamydomanas & - & 4 & - & - & 4 & - & 4 & - & 4 \\
\hline Chlorela & 3 & - & - & - & - & - & - & - & 3 \\
\hline Closterium & 1 & 1 & 1 & 1 & 1 & - & 1 & 1 & 1 \\
\hline Cyclotella & 1 & - & - & 1 & - & - & - & 1 & 1 \\
\hline Euglena & 5 & 5 & 5 & 5 & 5 & 5 & - & 5 & 5 \\
\hline Gomphonema & 1 & 1 & 1 & - & - & - & 1 & 1 & 1 \\
\hline Lepocinclis & 1 & 1 & 1 & 1 & - & - & 1 & 1 & 1 \\
\hline Melosira & - & - & - & - & - & - & - & - & 1 \\
\hline Micracyhis & 1 & 1 & - & 1 & - & 1 & - & - & 1 \\
\hline Micra etinium & 1 & 1 & - & - & - & 3 & - & - & 1 \\
\hline Navicula & 3 & 3 & 4 & - & - & 3 & 3 & 3 & 3 \\
\hline Nitzschia & 3 & 3 & 3 & 3 & - & 3 & 3 & 3 & 3 \\
\hline Oscillatoria & - & 4 & 4 & 4 & - & 4 & - & 4 & 4 \\
\hline Pondorina & 1 & - & 1 & 1 & 1 & 1 & - & - & 1 \\
\hline Phacus & 2 & 2 & 2 & 2 & 2 & 2 & - & 2 & 2 \\
\hline Phormidium & 1 & 1 & - & - & 1 & - & 1 & 1 & 1 \\
\hline Scenedesmus & 4 & 4 & 4 & 4 & 4 & 4 & 4 & 4 & 4 \\
\hline Stegioclonium & - & - & - & - & 2 & - & - & - & 2 \\
\hline Synedra & 2 & 2 & 2 & 2 & 2 & 2 & 2 & 2 & 2 \\
\hline Total Score & 31 & 33 & 28 & 27 & 23 & 25 & 20 & 28 & \\
\hline
\end{tabular}


Table.2 Species Index (Palmer, 1969)

\begin{tabular}{|c|c|c|c|c|c|c|c|c|c|}
\hline Algal Genera & $\begin{array}{l}\text { Dalvoi } \\
\text { Lake }\end{array}$ & $\begin{array}{l}\text { Karanji } \\
\text { Lake }\end{array}$ & $\begin{array}{c}\text { Kukkrahalli } \\
\text { Lake }\end{array}$ & $\begin{array}{c}\text { Mandakahalli } \\
\text { Lake }\end{array}$ & $\begin{array}{c}\text { Shettykere } \\
\text { Lake }\end{array}$ & $\begin{array}{l}\text { Hadhinaru } \\
\text { Lake }\end{array}$ & $\begin{array}{c}\text { Bogadi } \\
\text { Lake }\end{array}$ & $\begin{array}{c}\text { Billikere } \\
\text { Lake }\end{array}$ & $\mathbf{P}$ \\
\hline $\begin{array}{l}\text { Ankistrodesmus } \\
\text { falcatus }\end{array}$ & 3 & 3 & 3 & 3 & - & - & - & - & 3 \\
\hline Arthrospira jennari & 2 & - & 2 & - & 2 & - & 2 & - & 2 \\
\hline Chlorela vulgaris & - & - & 2 & - & - & - & - & - & 2 \\
\hline $\begin{array}{l}\text { Cyclotella } \\
\text { meneghiniani }\end{array}$ & 2 & - & - & 2 & - & - & - & 2 & 2 \\
\hline Euglena viridis & - & - & - & - & - & - & - & 1 & 1 \\
\hline Euglena acus & 6 & 6 & 6 & 6 & 6 & 6 & - & 6 & 6 \\
\hline $\begin{array}{l}\text { Gomphonema } \\
\text { parachus }\end{array}$ & 1 & - & - & - & - & - & 1 & 1 & 1 \\
\hline Melosira islandica & - & - & - & - & - & - & 2 & - & 2 \\
\hline $\begin{array}{l}\text { Navicula } \\
\text { cryptocephala }\end{array}$ & 1 & - & 1 & - & 1 & 1 & 1 & - & 1 \\
\hline $\begin{array}{l}\text { Nitzschia } \\
\text { cryptocephala }\end{array}$ & - & - & - & - & 1 & - & 1 & - & 1 \\
\hline Nitzscia palea & 5 & 5 & - & - & - & - & - & 5 & 5 \\
\hline Oscillatoria chlorine & - & - & 2 & 2 & 2 & - & - & - & 2 \\
\hline Oscillatoria limoso & - & - & - & - & - & - & - & - & 4 \\
\hline Oscillatoria princeps & 1 & 1 & - & - & 1 & - & - & - & 1 \\
\hline Oscillatoria puntrido & 1 & - & - & - & - & - & - & - & 1 \\
\hline Oscillatoria tenuis & - & - & - & - & 4 & - & - & - & 4 \\
\hline Pondorina morum & - & - & - & 3 & - & - & - & - & 3 \\
\hline $\begin{array}{l}\text { Scenedesmus } \\
\text { quadricands }\end{array}$ & - & 4 & 4 & 4 & 4 & 4 & 4 & 4 & 4 \\
\hline Stegioclonium tenne & - & - & - & - & - & - & - & - & 3 \\
\hline Synedra ulna & 3 & 3 & 3 & 3 & 3 & 3 & 3 & 3 & 3 \\
\hline Total & 25 & 22 & 23 & 23 & 24 & 14 & 14 & 22 & \\
\hline
\end{tabular}


Table.3 Ecological indices of pollution (OMNIDA software) based on the appearance of diatoms [Louis Laclereq (IDSE/5)]

\begin{tabular}{|l|c|c|c|c|c|}
\hline Name of the Lake & $\begin{array}{c}\text { o\% indices of } \\
\text { organic pollution }\end{array}$ & Rating & $\begin{array}{c}\text { \% indices of } \\
\text { inorganic pollution }\end{array}$ & $\begin{array}{c}\text { Rating } \\
\text { inside the Lake }\end{array}$ \\
\hline Dalvoi Lake & 72.73 & Very high & 27.27 & Moderate \\
\hline Karanji Lake & 62.50 & High & 37.50 & Moderate \\
\hline Kukkrahalii Lake & 66.67 & High & 33.33 & Moderate \\
\hline Mandakahalli Lake & 50.00 & High & 50.00 & High \\
\hline Shettykere Lake & 20.00 & Low & 60.00 & High & High \\
\hline Hadhinaru Lake & 20.00 & Low & 60.00 & High \\
\hline Bogadi Lake & 40.00 & Moderate & 60.00 & High \\
\hline Billkere Lake & 72.73 & Very high & 27.27 & Moderate & High \\
\hline
\end{tabular}

Table.4 Ranking of Lakes according to heavy Garrett based on Palmer algal index values

\begin{tabular}{|c|c|c|c|c|c|c|c|c|c|c|c|c|c|}
\hline Name of the Lake & $\begin{array}{l}\text { R1 } \\
\text { (5) }\end{array}$ & $\begin{array}{c}\mathrm{R} 1 \times \\
65\end{array}$ & $\begin{array}{l}\text { R2 } \\
\text { (4) }\end{array}$ & $\begin{array}{c}\text { R2 } \times \\
69\end{array}$ & $\begin{array}{l}\text { R3 } \\
\text { (3) }\end{array}$ & $\begin{array}{r}\mathbf{R 3} \\
\times 73\end{array}$ & $\begin{array}{c}\mathbf{R} 4 \times \\
(2)\end{array}$ & $\begin{array}{c}\text { R4 } \times \\
18\end{array}$ & $\begin{array}{c}\mathbf{R 5} \\
\times(1)\end{array}$ & $\begin{array}{c}\mathbf{R 5} \times \\
88\end{array}$ & $\begin{array}{l}\text { Total } \\
\text { score }\end{array}$ & $\begin{array}{c}\text { Average } \\
\text { score }\end{array}$ & Rank \\
\hline Dalvoi Lake & 1 & 65 & 1 & 69 & 3 & 219 & 3 & 234 & 7 & 616 & 1203 & 60.12 & 1 \\
\hline Karanji Lake & 1 & 65 & 3 & 207 & 2 & 146 & 3 & 234 & 6 & 528 & 1180 & 59.00 & 2 \\
\hline Kukkrahalii Lake & 1 & 65 & 2 & 138 & 3 & 219 & 3 & 234 & 4 & 352 & 1008 & 50.40 & 3 \\
\hline Mandakahalli Lake & 1 & 65 & 2 & 138 & 1 & 73 & 2 & 156 & 2 & 176 & 608 & 30.40 & 8 \\
\hline Shettykere Lake & 1 & 65 & 2 & 138 & 0 & 00 & 3 & 234 & 4 & 352 & 789 & 39.45 & 5 \\
\hline Hadhinaru Lake & 1 & 65 & 2 & 138 & 2 & 146 & 2 & 156 & 2 & 176 & 622 & 31.10 & 7 \\
\hline Bogadi Lake & 0 & 0 & 2 & 138 & 2 & 146 & 1 & 78 & 4 & 352 & 714 & 35.70 & 6 \\
\hline Billkere Lake & 1 & 65 & 2 & 138 & 2 & 146 & 2 & 156 & 5 & 440 & 805 & 40.25 & 4 \\
\hline
\end{tabular}


Therefore it is essential that the selected organisms that are always present at high level organic pollution.

In conclusion, Palmer's algal indices of all the Lakes were categorized as organically polluted. One of the well developed techniques for detection of organic pollution is the OMNIDA GB 5.3 software. This software detects only diatoms which indicate level of organic pollution. It also gives the information on the level of contamination of water bodies as well identifies which diatoms are autochthonous and which are allochthonous. Diatoms remain at benthic region in the epiphytic forms and can serve as good indicators of organic pollution. It is very important to determine the quality of any water with the help of well developed software that can give precise results. The result can be used for the measurement of heavily polluted Lakes in future studies. The algae that are autochthonous and idiosyncratic species that appear or disappear suddenly in the Lakes can be marked and used for longer duration. The WQI of Dalvoi Lake, Karanj Lake and kukkrahalli Lake were highly organically polluted and species of euglena, scenedesmus, lepocinclis and synedra are the top indicators of the water quality. The ranking techniques are also another important aspect which enables researcher to place the sites under study from most polluted to the least polluted and compare similar sites conservation strategies. The combination of all newer techniques can be useful in conservation strategy of Lake Ecosystem. The present study indicated that the 8 Lakes were organically polluted but the degree of pollution varied to a greater extent. These techniques help in improving water quality in all the Lakes.

\section{Acknowledgement}

I deeply express sincere thanks to my guide Professor Late S.P. Hosmani for his guidance to research. Authors are thankful UAS (B) Bangalore and Dean (Agri.), CoA, VC Farm, Mandya and University of Mysore and also UGC for financial assistance.

\section{References}

APHA, AWWA, WPCF (2012): Standard method for examination of water and waste water, $19^{\text {th }}$ edn. APHA, Inc Washington DC, pp.

Atmar W and B.P. Patterson (1993): The nestedness temperature calculator. A visual basic programme including 294 presence absence matrices A/C Research Inc. University Parle NM and Filed Museum, Chicago IL, pp.

Balanco IA and Blanco. 2012. The Duro diatom index (DDI) for river water quality assessment in N.W. Spain. Design and validation, Environ, Monit Assess DVI 10.1007/S 10661-01226072.

Darligton P.J. 1957. 200 geography: The geographical distribution of animals willey.

Danbenmire R. 1975. Floristic plant geography of eastern Washington and northern Idaho J Biogeoorg 2:1-18.

Desikachary T.V., 1959. Cyanophyta, ICAR publication, New Delhi, pp.686

Gandhi H.P., 1998. Fresh water diatoms of central Gujarat.

Garrett, H. 1924. An empirical study of the various methods of combining incomplete orders of merit ratings. $J$. of educational psychology (15)3:157-171.

Hosmani S.P. and Bharathi. 1980. Algae as indicators of organic pollution. Phykos 19(1): 23-26.

Hosmani S. P. 2010. Phytoplanton diversity in Lakes of Mysore district, Karnataka state, India. The Ecoscan., 4(1) 53-57.

Hosmani S. P. 2012. Application of benthic diatom community in Lake water quality monitoring, Phykos., 42(2)7479. 
Hosmani S. P and Mrunthunjaya, T. B. 2013. Impact of plankton diversity on the water quality index in a Lake at Thirumakundal Narsipura, Mysore District. International Journal of innovative research in science engineering technology., 7(5):14341441.

Hultein, E. 1937. Outline history of Arctic and Boreal biota during quaternary period. Thule Stockholm.

Kelly M.G. 2006. A comparison of diatoms with other phytobenthos as indicator of ecological status of streams of northern England. Proceedings of the $18^{\text {th }}$ International Diatom Symposium. Bristol. pp. 131-151.

Lackey, J. P., 1938. Public health reports 53: 2080-2091.

Lecoinitec, M. C and Prygeil J. 2003. OMNIDA: Diatom index software including diatom data base with taxonomic names references and codes of 11645 diatom taxa, pp.

Louis - Laclereq, 2008. IDSE Diatom index of Saprobity - Eutrophication Conception (in Leconite et. al., 1993).

Mahadev and Hosmani., 2004. Community structure of cyanobacteria in two polluted Lakes of Mysore city, Nat. Env. Pollution Tech. 3(4): 523-526.

Mahadev and Syed Akheel Ahmeed., 2008. Phytoplankton density in relation to environmental variables in Dalvoi Lake at Mysore, India., Asian J. of Environmental Science., 3 (1): 14-16.

Mahadev, J., Nagarathnamma and Akheel Syed Ahmeed., 2009. Physico chemical factors influencing the growth of diatom in two habitats of Mysore., Asian J. of Environmental Science., 4 (1): 12-14.

Nyguard, G. 1976. Talverna Danst phytoplankton cyledanal, pp. 22.

Palmer G. M. 1959. Algae of water supplies US Publ Health some publication 657 185

Philipose, M.T. 1960. Chlorococcales, ICAR publication, New Delhi.

Prescott G.W. 1982. Algae of the western great Lakes area, Otto Kaetz Science publishers West Germany, pp. 997

Seatt A and Prescott, G. W. 1961. Indonesian Desmides Hydrobiologia., 25(4):131

Taylor, J. C., Herding, W. R and Archibald, C.G.M. 2007. An illustrated guide to common diatom species from South Africa, pp: 282.

\section{How to cite this article:}

Mahadev, J., G. Sugeetha, N.S. Pankaja and Shivakumar, K.V. 2019. Alga as an Indicator of Water Quality in Fresh Water Bodies of Mysore, Karnataka, India. Int.J.Curr.Microbiol.App.Sci. 8(03): 2264-2271. doi: https://doi.org/10.20546/ijcmas.2019.803.270 